Cornell Law Library

Scholarship@Cornell Law: A Digital Repository

Cornell Law Faculty Publications

Faculty Scholarship

3-1-1989

\title{
Commentary on "On the Nature of Bankruptcy": Bankruptcy and Bargaining
}

Theodore Eisenberg

Cornell Law School, ted-eisenberg@lawschool.cornell.edu

Follow this and additional works at: http://scholarship.law.cornell.edu/facpub

Part of the Bankruptcy Law Commons, and the Legal History, Theory and Process Commons

\section{Recommended Citation}

Eisenberg, Theodore, "Commentary on "On the Nature of Bankruptcy": Bankruptcy and Bargaining" (1989). Cornell Law Faculty Publications. Paper 422.

http://scholarship.law.cornell.edu/facpub/422

This Article is brought to you for free and open access by the Faculty Scholarship at Scholarship@Cornell Law: A Digital Repository. It has been accepted for inclusion in Cornell Law Faculty Publications by an authorized administrator of Scholarship@Cornell Law: A Digital Repository. For more information, please contact jmp8@cornell.edu. 


\title{
COMMENTARY ON "ON THE NATURE OF BANKRUPTCY”: BANKRUPTCY AND BARGAINING
}

\author{
Theodore Eisenberg*
}

\begin{abstract}
$A^{\mathrm{T}}$ $T$ a conference on bargaining, it should not be surprising that there is more than one perspective on the relationship between bankruptcy and bargaining. Dean Jackson and Professor Scott's article emphasizes a hypothetical bargain to be struck by idealized participants in a firm. It explores the relationship between bankruptcy and that bargain. By imagining what that bargain would look like, Jackson and Scott construct new justifications for bankruptcy law's distributional rules. Such a theory, however, is subject to reservations about the depth of insight that can be gained from examination of purely theoretical bargains. Stripped of real-world characteristics, hypothetical bargains struck by hypothetical actors cannot hope to capture the full range of human interaction. Nevertheless, Jackson and Scott's discussion is valuable because it provides a fresh outlook on difficult questions of bankruptcy theory.

But another equally fruitful relationship between bankruptcy and bargaining exists. This relationship is not between bankruptcy and the hypothetical bargain to which creditors might agree ex ante; rather, it is between bankruptcy and the real-world bargaining that attends most commercial disputes. As this relationship has not been examined extensively, I wish to introduce it here. After analyzing the relationship between bankruptcy and real-world bargaining, this Comment offers a limited critique of Jackson and Scott's theory.
\end{abstract}

\section{BANKRUPTCY AND REAL-WORLD BARGAINING}

\section{A. The Dominance of Bargained Results}

A major theme of Jackson and Scott's article is illuminating why and how the distributional rules within bankruptcy differ from nonbankruptcy distributional rules. Most commentators advocate a presumption favoring preserving nonbankruptcy entitlements in bankruptcy. ${ }^{1}$ Departures require justification. To preserve nonbankruptcy entitlements, those entitlements must be identified. An identifiable state law result must be found that bankruptcy law can strive to preserve in bankruptcy.

* Professor of Law, Cornell Law School.

1 See, e.g., T. Jackson, The Logic and Limits of Bankruptcy Law 20-24 (1986); Eisenberg, Bankruptcy Law in Perspective, 28 UCLA L. Rev. 953, 957-58 (1981). 
What state law entitlements count for purposes of emulation by bankruptcy law? Most analyses include only formal status under state law, including whether a creditor is secured, has a judgment, and the like. The analyses ignore bargained outcomes, those shaped but not completely defined by the parties' formal entitlements. Because bargaining dominates outcomes both inside and outside of bankruptcy, however, a broader range of nonbankruptcy outcomes should be acknowledged as existing under state law. Similarly, a broader range of bankruptcy outcomes must be accepted as compatible with state law outcomes. A bargain-based view of bankruptcy may provide a helpful positive explanation for some of bankruptcy's rules, including several that Jackson and Scott explore in their article. This view requires more emphasis on bankruptcy's internal processes than currently exists.

Thus, in comparing bankruptcy outcomes with nonbankruptcy outcomes, there has generally been too narrow a view of "the" nonbankruptcy result appropriate for comparison with bankruptcy outcomes. Even an approach limited to formal nonbankruptcy rules affecting financially troubled entities can lead to several different bases for comparison. ${ }^{2}$ State law has mechanisms triggered by financial difficulty for dissolution, assignments for the benefit of creditors, and receiverships. Each of these state law mechanisms may provide an appropriate analogy to bankruptcy. ${ }^{3}$

But the range of possible state law outcomes is not limited to those dependent on formal state procedures. The bulk of nonbankruptcy results, I suspect, consists of negotiated settlements that never occupy a court docket and never involve formal proceedings. Sketchy empirical evidence in other areas supports the hypothesis that disputes relating to financially troubled entities often settle without formal invocation of the nonbankruptcy rules that govern the parties' entitlements and distributional priority. Bargained results dominate, often with less than strict attention to the parties' formal entitlements. ${ }^{4}$ In many areas, of those disputes that do lead to filings in court, the majority settle. ${ }^{5}$

2 Eisenberg, A Bankruptcy Machine that Would Go of Itself, 39 Stan. L. Rev. 1519, 152324 (1987).

3 Id.

4 See Macaulay, An Empirical View of Contract, 1985 Wis. L. Rev. 465; Macaulay, NonContractual Relations in Business: A Preliminary Study, 28 Am. Soc. Rev. 55, 60-62 (1963); Mueller, Contract Remedies: Business Fact and Legal Fantasy, 1967 Wis. L. Rev. 833, 836-37. For a brief survey of empirical work in an important related branch of contract scholarship, see Macneil, Relational Contract: What We Do and Do Not Know, 1985 Wis. L. Rev. 483, 508-11 (suggesting the limits of existing empirical studies).

5 See The Political Economy of Antitrust: Principal Paper by William Baxter 10-23 (R. Tollison ed. 1980) [hereinafter Political Economy]; A. Conard, J. Morgan, R. Pratt, C. Voltz, \& R. Bombaugh, Automobile Accident Costs and Payments: Studies in the Economics of 
The dominance of bargained settlements softens formal entitlements. Bankruptcy law should not try to replicate state law without accounting for the bargained outcomes that dominate commercial dealings. This suggests that bankruptcy law'should not hope always to replicate formal state law entitlements. Rather, an alternative and not wholly competing aspiration is to promote bargained solutions in bankruptcy, with less concern about whether the solutions depart from state law entitlements. In the real world, those entitlements play a less central role than current approaches to bankruptcy law reflect. Bargained state law outcomes ought to be included in the - set of baseline results against which bankruptcy's performance is measured.

\section{B. The Shadow of State Law}

To the extent that law matters, the emphasis on bargaining in bankruptcy and on bargained state law results does not change the law that governs the bargaining process. The nonbankruptcy bargains that dominate commercial life are struck in the shadow of nonbankruptcy law, ${ }^{6}$ a rule-based distributional regime in which creditors prevail over shareholders, secured creditors prevail over unsecured creditors, and unsecured creditors usually must take action to become lien creditors before having any rights in the debtor's property. Although emphasizing bargained solutions tolerates more departures from the rule-based regime than does strict focus on state law entitlements, the regime continues to influence the bargain. Consistency between bankruptcy and nonbankruptcy law commands that the nonbankruptcy regime continue to cast the shadow dominating bargaining in bankruptcy.

In fact the nonbankruptcy regime continues to dominate in bankruptcy. Jackson and Scott understandably emphasize some of the many ways in which bankruptcy's distributional effects depart from nonbankruptcy law.

Injury Reparation 155-56 (1964); H. Ross, Settled Out of Court: The Social Process of Insurance Claims Adjustment 215-16 (2d ed. 1980); Danzon \& Lillard, Settlement Out of Court: The Disposition of Medical Malpractice Claims, 12 J. Legal Stud. 345, 365 (1983) (finding that less than $10 \%$ of tort cases are litigated to a verdict); Eisenberg \& Schwab, The Reality of Constitutional Tort Litigation, 72 Cornell L. Rev. 641, 674 table VIII (1987) (high success rate, with relatively few tried cases, in control group of non-civil rights cases); Franklin, Chanin, \& Mark, Accidents, Money, and the Law: A Study of the Economics of Personal Injury Litigation, 61 Colum. L. Rev. 1, 10-11, 13-14 (1961) (98\% of all New York City tort claims are disposed of through the bargaining process); Jones, An Empirical Examination of the Resolution of Shareholder Derivative and Class Action Suits, 60 B.U.L. Rev. 542, 545 (1980) (70.7\% of shareholder derivative suits settle); Schwab \& Eisenberg, Explaining Constitutional Tort Litigation: The Influence of the Attorney Fees Statute and the Government as Defendant, 73 Cornell L. Rev. 719, 733 table IV (1988) (high success rate, with relatively few tried cases, in control group of non-civil rights cases).

$6 \mathrm{Cf}$. Mnookin \& Kornhauser, Bargaining in the Shadow of the Law: The Case of Divorce, 88 Yale L.J. 950 (1979) (effect of divorce law on bargaining). 
That, after all, is the phenomenon they seek to explore. In doing so, they necessarily downplay the continuing importance of nonbankruptcy law in bankruptcy. But whatever the effects of bankruptcy-imposed delay on secured claims, bankruptcy law recognizes that the secured claimants are the ones entitled to adequate protection. Secured claimants have liens on property that survive bankruptcy or must be paid off in full. ${ }^{7}$ Obtaining lien status under state law in general is sufficient to entitle a claimant to lien status in bankruptcy. ${ }^{8}$ These results can be explained only by reference to a norm of fidelity to secured claimants' nonbankruptcy entitlements. In general, no claimant participates in bankruptcy unless it has a claim under nonbankruptcy law. ${ }^{9}$ In the Texaco-Pennzoil litigation, no one ever forgot Pennzoil's state law entitlements in the course of their bargaining in bankruptcy. ${ }^{10}$

It is difficult to imagine alternative mechanisms entitling one to participation. Given the many ways in which bankruptcy honors state law entitlements, it is only at the margin that many of those entitlements are rearranged in bankruptcy. In short, the legal shadow that dominates bargaining in bankruptcy merely blurs the edges of the legal shadow that dominates outside of bankruptcy. Its basic shape is retained.

\section{Bankruptcy Rules that Promote Bargaining}

A bargain-based view of bankruptcy provides a positive explanation for bankruptcy rules that may be as compelling as the explanation that is based on the common disaster heuristic. It is possible that the two visions do not compete.

Bankruptcy law contains many rules that encourage or coerce parties into continuing to deal with the debtor. The Bankruptcy Code grants priority to nearly all postpetition expenses, ${ }^{11}$ thereby assuring workers and postpetition lenders that their continuing interaction with the debtor provides claims that rank ahead of prepetition claims. This important distributional rule can be justified on few grounds other than its encouragement of participation with the debtor. The executory contract provisions discussed in the Jackson and Scott article, unlike the express administrative priority provisions, do not invite parties to deal with the debtor; they require them to do so. ${ }^{12}$ Despite financial dislocations that, outside bankruptcy, would warrant termination

7 See, e.g., T. Eisenberg, Bankruptcy and Debtor-Creditor Law 583 (2d ed. 1988).

811 U.S.C. $\$ 101$ (33) (Supp. IV 1986) (definition of lien).

911 U.S.C. $\$ 101$ (4) (1982) (definition of claim).

10 See Mnookin \& Wilson, Rational Bargaining and Market Efficiency: Understanding Pennzoil v. Texaco, 75 Va. L. Rev. 295 (1989).

1111 U.S.C. $\S \S 503,507(a)(1)$ (1982 \& Supp. IV 1986).

12 Id. $\S 365$. 
of contracts or declarations of breach, bankruptcy law's executory contract provisions require parties to continue to deal with the debtor. ${ }^{13}$ The debtor or the trustee often can go so far as to assign performance obligations under contract to third parties. ${ }^{14}$ The command to continue dealing with the debtor can lead to bargaining conversations that might not exist absent these provisions.

Many other bankruptcy law provisions soften the sharp edges of creditors' state law rights. They do so not through express distributional provisions but through many of the provisions that Jackson and Scott highlight. The automatic stay on reclamation ${ }^{15}$ and the indefiniteness of what constitutes adequate protection ${ }^{16}$ mean that secured parties who could take firm stands in the nonbankruptcy rule-based regime must reconsider their positions during bankruptcy bargaining. They cannot merely insist on immediate return of their collateral or its value. Creditor and claimant rights in bankruptcy often depend on the valuation of property or of the firm. The amount of a secured creditor's secured claim, for example, is limited by the value of the collateral, ${ }^{17}$ which is a matter for the court to decide. A debtor's power to classify unsecured claims in Chapters 11,12 , and $13^{18}$ is a powerful bargaining tool that mirrors his de facto ability to treat creditors differently outside of bankruptcy. ${ }^{19}$

One effect of all of these rules is to bring parties with firm state law rights to the bargaining table. Parties go there often outside of bankruptcy anyway, despite their formal state law entitlements. Perhaps it is not surprising that so many rules encourage bargaining inside bankruptcy.

\section{The Problem of Uncertainty Generating Litigation}

Bankruptcy law promotes bargaining by creating uncertainty about participant rights. The secured creditor who "knows" that it is entitled to a particular amount in bankruptcy has little incentive to bargain. The uncertainty that bankruptcy creates about such a creditor's rights, through limits on reclamation and adequate protection, brings the creditor to the bargaining table.

\footnotetext{
13 Id. § 365(b), (e), (f).

1411 U.S.C. \& 365(f) (1982). But see 11 U.S.C. § 365(c) (Supp. IV 1986) (enumerating exceptions to $\S 365(f))$.

1511 U.S.C. § 362 (Supp. IV 1986).

16 See United Savings Ass'n of Tex. v. Timbers of Inwood Forest Assocs., 108 S. Ct. 626 (1988).

1711 U.S.C. § 506(a) (1982).

18 Id. $\S \S 1122,1222(b)(1), 1322(b)(1)$.

19 This power is reflected in the notion that a preference (paying one creditor ahead of others) is not a fraudulent conveyance. E.g., T. Jackson, supra note 1, at 123-24, 147.
} 
Yet while uncertainty fuels bargaining it also fuels litigation. When both parties agree on the outcome of a dispute there is little reason to litigate. Only when they disagree on the expected outcome does litigation result. ${ }^{20}$ Can the promotion of bargaining in bankruptcy be normatively desirable when it simultaneously encourages litigation? And should bargaining be promoted by introducing uncertainty, a characteristic that powers litigation and discourages settlement?

Although the conventional wisdom is that uncertainty fuels litigation, the uncertainty Texaco's bankruptcy filing generated about the parties' positions in the Texaco-Pennzoil litigation fueled settlement. The filing clouded the status of Pennzoil's judgment ${ }^{21}$ and the bankruptcy judge's ruling limiting Texaco's period of exclusivity in which to file a plan ${ }^{22}$ muddied Texaco's crystal ball. Peter Schuck describes a similar phenomenon in his analysis of the Agent Orange litigation. ${ }^{23}$ In his description, uncertainty was one of the factors that generated the settlement, a result contrary to some conventional wisdom. ${ }^{24} \mathrm{He}$ states: "This finding of a strong positive relationship between uncertainty of outcome and settlement, so apparent to all of the participants, suggests that the concept of uncertainty used in the model of the decision to litigate or to settle ... which posits that uncertainty will actually impede settlement, is too broad." 25

The Texaco-Pennzoil and Agent Orange experiences suggest reevaluating the litigation models that place such great weight on uncertainty. Although such models are helpful in thinking through the litigation process, empirical tests of them also raise doubts about their current completeness and predictive power. ${ }^{26}$ For the moment, further work on litigation models appears

20 See, e.g., Political Economy, supra note 5, at 18-21 (suggesting that litigation occurs only if the parties' estimates of the probability of a plaintiff's judgment substantially diverge); Priest \& Klein, The Selection of Disputes for Litigation, $13 \mathrm{~J}$. Legal Stud. 1, 17 (1984) (agreement over the outcome leads parties to drop out of litigation); Schwab \& Eisenberg, supra note 5, at 742-43; Shavell, Suit, Settlement, and Trial: A Theoretical Analysis Under Alternative Methods for the Allocation of Legal Costs, 11 J. Legal Stud. 55, 56-57 (1982) (parties will settle if their ex ante evaluations correspond); Trubek, Sarat, Felstiner, Kritzer \& Grossman, The Costs of Ordinary Litigation, 31 UCLA L. Rev. 72, 76 n.9 (1983) (discussing the "optimism" model, in which trial ensues when both plaintiff and defendant are excessively optimistic about the likely outcome).

21 Mnookin \& Wilson, supra note 10.

22 Id.

${ }^{23}$ Schuck, The Role of Judges in Settling Complex Cases: The Agent Orange Example, 53 U. Chi. L. Rev. 337 (1986).

24 See supra note 20.

25 Schuck, supra note 23 , at 346 n.30.

26 See Schwab \& Eisenberg, supra note 5, at 756-58 (failing to detect increase in civil rights filings that litigation models seemingly predict). 
necessary before discounting the observed occurrence of uncertainty promoting settlement.

How one feels about the promotion of bargaining and the encouragement of uncertainty also depends on the outcome to which the nonbargained solution is compared. Consider, for example, the Texaco-Pennzoil litigation. The result bargained in the shadow of uncertainty needs to be compared to the result that would have occurred in the face of certainty. If Pennzoil knew it could enforce its judgment without bankruptcy impediments, what would have happened? Under one view, Pennzoil might have gone ahead and effectively destroyed Texaco, causing the loss of the going concern value of a substantial economic entity. Introducing some doubt. into Pennzoil's world may, on this view, have been normatively desirable. ${ }^{27}$ If, on the other hand, one believed Texaco could satisfy the judgment without major financial dislocation, the departure from the certain solution would be less justifiable.

\section{E. Consequences of the New Perspective}

The effect of accounting for bargained settlements in thinking about bankruptcy is more a matter of emphasis than a radical new approach. The new emphasis does, however, have important consequences. First, theorists should be less concerned about justifying each bankruptcy departure from state law entitlements. Strict rule-based distributions under state law outside of bankruptcy probably are the exception, not the rule. Less well-known (and perhaps less knowable) bargained solutions constitute a more elusive class of state law results to which bankruptcy results should be compared. Thus, departures from what is usually presumed to be the strict nonbankruptcy pecking order are less troublesome than they may appear to be.

Second, one should focus more on the process of bargaining in bankruptcy. Despite the many bankruptcy issues litigated, it is likely that most results in bankruptcy settings, like most results outside of bankruptcy, are reached through bargaining and settlement. Indeed, emphasizing bargained solutions may be a way that bankruptcy law can come closest to fidelity to nonbankruptcy outcomes. Because the bankruptcy process itself introduces new elements into the bargaining process, we should not expect perfect replication of formal nonbankruptcy outcomes. As Mnookin and Wilson emphasize in their study of the Texaco-Pennzoil dispute, the bankruptcy judge becomes an important new participant in the financial drama. ${ }^{28}$ Once in

27 Presumably, Pennzoil would have enforced its rights to the limit, subject only to fear that enforcing its judgment would so diminish Texaco's value as to endanger Pennzoil's ability to collect.

28 Mnookin \& Wilson, supra note 10. 
bankruptcy, new players, such as Carl Icahn, may appear on the horizon. These important new ingredients mean that the bargained-for solution in bankruptcy cannot replicate either a formal rule-based nonbankruptcy distribution or a bargained-for nonbankruptcy solution.

If bargained solutions dominate inside and outside of bankruptcy, comparisons between bankruptcy and nonbankruptcy results become more difficult than would be the case if all distributions were mandated by state law. The range of bargained solutions must be broader than the range of strict rule-based distributions. Recognizing the role of bargaining in and out of bankruptcy means recognizing the likelihood of greater variance in outcomes between settings.

\section{The Common Disaster Model}

None of the above necessarily undermines anything in Jackson and Scott's article. It does suggest, and they do not deny, a multifaceted relationship between bankruptcy and bargaining that transcends any individual theory of bankruptcy. Shifting attention to the specific theory Jackson and Scott develop, the emphasis in what follows is not on the formal development of their theory, but on the portions of bankruptcy law they use to test that theory.

Jackson and Scott explore three areas of bankruptcy law in testing their hypotheses: (1) the bankruptcy trustee's powers, (2) the cost of delay imposed on secured creditors, and (3) Chapter 11 reorganization plans. In each area, their discussion provides some support for the modified creditor's bargain. The kind of ringing, conclusive support one might hope for is, however, lacking. And little of the support that is marshaled suggests that the modified creditor's bargain is superior to the simpler theories that might underlie much of bankruptcy law. I suspect that some observers reluctant to embrace a hypothetical creditors' bargain might nevertheless endorse Jackson and Scott's emphasis on risk sharing as a positive explanation for many bankruptcy rules. Whether or not creditors would agree to risk sharing in advance, it is appealing as a possible justification for much of bankruptcy law.

\section{A. The Trustee's Avoiding Powers}

\section{The Trustee's Section 544(a) Power}

Jackson and Scott assert that section 544(a) of the Bankruptcy Code has distributional effects at odds with nonbankruptcy distributions. After considering some traditional justifications for the trustee's section 544(a) power, they ask whether their creditors' bargain/common disaster vision of bankruptcy provides additional insights. They conclude that a nonperfecting 
secured creditor is not disclosing key information important to the collective interests of all creditors; under this view, "section 544(a) is not an equalizing rule as much as it is a leveling rule. It is a necessary prophylactic to ensure cooperative behavior by powerful creditors in the critical period prior to bankruptcy."

Does this explanation of section 544(a) ring true? ${ }^{29}$ Section 544(a) does provide secured parties with an incentive to comply with state law regarding perfection of their security interests by imposing a penalty on secured parties who do not do so. Although the structure of this point is acceptable, its weight is troublesome. The secured-party-incentive aspect of section 544(a) strikes me as a minor theme of the provision.

First, state law supplies secured parties with substantial incentives to comply with its dictates. Although an unperfected security interest does not automatically become subordinate to mere unsecured creditors, unperfected secured parties run several real risks under state law. If an unsecured creditor obtains an attachment or a judgment lien, the unperfected secured party loses its priority. ${ }^{30}$ If another secured party perfects its security interest, the nonperfecting secured party loses priority as against this later lender. ${ }^{31}$ In general, an unperfected security interest is vulnerable under state law to many interests and the nonperfecting secured party cannot know in advance whether or when its interests will be subordinated to those of mere unsecured creditors. Secured parties who do not perfect, yet are not subordinated, are lucky. They rvould be foolish to count on their failure to give the world notice as a way of obtaining an advantage over unsecured creditors. This is the one sure way to render themselves vulnerable to such interests. Secured parties who fail to perfect most often have erred, not intentionally misled other creditors.

Second, when secured parties do try to mislead, other aspects of state law and bankruptcy law address their misbehavior. A secured party who intentionally misleads other creditors probably is a party to a fraudulent conveyance that is vulnerable under both section 544(b) and section $548 .{ }^{32}$ As a conscious wrongdoer, such a secured party loses the protection normally afforded to transferees of fraudulent conveyances. ${ }^{33}$ One cannot deny that section 544(a) has the effect Jackson and Scott assert. It penalizes secured

29 Jackson and Scott's claims for their § 544(a) analysis are modest. They acknowledge several possible explanations for $\S 544$ (a) and do not purport to select among the rules.

30 U.C.C. $\S 9-301$ (1987).

31 Id. $\$ 9-312(5)$.

3211 U.S.C. $\S \S 544(b), 548$ (1982 \& Supp. IV 1986).

33 Unif. Fraudulent Conveyance Act $\S 9$, 7A U.L.A. 577 (1985) (superseded 1984); 11 U.S.C. § 548(c) (Supp. IV 1986). 
parties who would sacrifice the size of the pie to their own self-interest. This effect, however, is a minor feature of section 544(a).

\section{Moore v. Bay and Section 544(b)}

Jackson and Scott provide a second concrete illustration of a bankruptcy rule explainable by the common disaster approach. They assert a firmer foundation than heretofore has been found for the rule of Moore v. Bay. ${ }^{34}$ Supplying a sound basis for that case would be regarded in the bankruptcy world as an accomplishment. Moore is an intellectual orphan, with many detractors and few defenders. ${ }^{35}$

Why is Moore so suspect? The case's bad reputation stems from the fact that its results are inconsistent with state law. Consider a case, In re Plonta, ${ }^{36}$ in which Moore leads to questionable results. In Plonta, a Michigan secured party delayed perfecting its security interest. Under state law, the secured party's interest was vulnerable to unsecured creditors who became creditors during the gap in time between the grant of security and perfection of the interest. The trustee found such a creditor, who was owed ten dollars and, using that creditor's status and section 544(b), invalidated a security interest in $\$ 2300$ worth of collateral. As Moore has been read, the numbers could have been even more drastic and its principle would apply. A one-dollar unsecured creditor might have enabled the trustee to undo a multimillion dollar transaction.

Moore's result is troublesome because state law would not attach such a drastic consequence to a minor flaw. In general, a minor creditor can, under state law, be paid in full and thereby lose standing to object to flaws in the debtor's transactions. ${ }^{37}$ Thus, outside of bankruptcy the $\$ 2300$ secured party in Plonta could have paid the ten-dollar creditor ten dollars and eliminated that creditor's claim to the collateral. Once in bankruptcy, though, Moore's rule taints the entire transaction, and there is no corresponding ability to pay off the unsecured creditor against whom the grant of security is vulnerable. This discontinuity between the bankruptcy result and the nonbankruptcy result is troublesome.

Jackson and Scott seek to support Moore's rule by hypothesizing a tainted leveraged buyout, which presumably is subject to fraudulent conveyance attack. They claim that "[i]f the probability of detection of a malignant buyout is less than 1.0, the effective sanction can be raised by increasing the nominal sanction in those cases where the transaction is determined to vio-

\footnotetext{
34284 U.S. 4 (1931).

35 See 2 G. Gilmore, Security Interests in Personal Property $\S 45.3 .1$, at 1290 (1965).

36311 F.2d 44 (6th Cir. 1962).

37 U.C.C. $\S 9-506$ (1987).
} 
late the interests of the collective." The overkill of Moore's rule exists to offset the underkill of the rules that fail to detect and to regulate other tainted leveraged buyouts.

Is this example persuasive support for the common disaster theory? One problem with it is that Moore's rule, as applied to a tainted leveraged buyout, may not be overkill. If it is not, then Moore's rule does not raise the effective sanction; it imposes the appropriate sanction. To understand why Moore's rule may not be too harsh a sanction, it is necessary to identify the basis for attacking a tainted leveraged buyout.

Several attacks on leveraged buyouts are possible, but the most common is one based on the portion of fraudulent conveyance law that enables creditors to attack transfers by debtors that were made for inadequate consideration. ${ }^{38}$ For example, in a leveraged buyout the acquired company may grant a security interest to a lending institution to secure loans that an acquiring entity effectively uses to buyout the acquired company's shareholders. In such a transaction no direct consideration flows to the acquired company even though it bears the burden of having granted a security interest in its assets. The acquired company's creditors may believe that the company has incurred an obligation without receiving consideration that would be of value to them as creditors of the company. ${ }^{39}$

Such a leveraged buyout will be vulnerable if, at the time the acquired company incurs its challenged obligation, the acquired company is insolvent. ${ }^{40}$ This is an express requirement of fraudulent conveyance attacks based on inadequate consideration. ${ }^{41}$ Thus, the debtor, at the time of the conveyance, has creditor claims against it large enough to consume all of its net worth. As applied to such a case, Moore's rule invalidates the transfer of a security interest completely, regardless of the absolute amount owed creditors who could attack the transaction under state law. ${ }^{42}$ Yet there is a group of creditors owed more than the net worth of the firm. Moore's undoing of the entire transaction is not clearly an overreaching sanction on such facts. It is, therefore, difficult to view Moore as an overreaching sanction designed

38 Unif. Fraudulent Conveyance Act $\S \S 4,5,7 A$ U.L.A. 474, 504 (1985) (superseded 1984); 11 U.S.C. § 548(a)(2)(A) (Supp. IV 1986). Related provisions allow attacks on transfers leaving entities with unreasonably small capital. See Unif. Fraudulent Conveyance Act $\S 5$, 7A U.L.A. 504 (1985) (superseded 1984); Unif. Fraudulent Transfer Act § 4(a)(2), 7A U.L.A. 653 (1985); 11 U.S.C. § 548(a)(2)(B)(ii) (Supp. IV 1986).

39 See, e.g., TeleFest, Inc. v. VU-TV, Inc., 591 F. Supp. 1368 (D.N.J. 1984) (failed fraudulent conveyance attack).

40 Id. at 1376.

41 See supra note 38.

42 See Moore, 284 U.S. 4, 5 (1931). 
to make up for cases in which tainted leveraged buyouts are not detected. ${ }^{43}$

\section{B. Reimbursement for Delay Costs}

Of the illustrations Jackson and Scott provide, the common disaster heuristic is most appealing in explaining rules spreading the cost of delay in bankruptcy. Whether or not one assumes that creditors would agree ex ante to the existing system, there is a simplicity (and perhaps therefore efficiency) in not allowing parties to demand compensation for bankruptcy's delays. Bankruptcy can be viewed as suspending the passage of legal time while parties rearrange the debtor's affairs. The legal clock starts ticking again only when matters are resolved. There is no state law rule to depart from because state law cannot hold creditors at bay and discharge debts to the extent federal bankruptcy law can. Delay on the scale possible under the Bankruptcy Code cannot exist under state law.

\section{Reorganizations}

Jackson and Scott state that assuming the existence of complex relational interactions among those interested in a Chapter 11 debtor bolsters the case for reorganization. Firm-specific investments and synergistic interactions render a simple sale of the troubled corporation less suitable as a method of realizing its full value, making reorganization the value-maximizing solution. Working from their stated justifications for reorganization, they also find support for risk sharing in existing Chapter 11 rules.

I have no quarrel with the evidence they marshal for risk sharing as an attribute of Chapter 11. The evidence establishing the distributional effects of reorganization supports their point. Their conclusion is further bolstered by the observation that a claim is not impaired in Chapter 11, and therefore not entitled to vote on a reorganization plan, if the debtor cures prepetition defaults, pays any damages, and reinstates the obligation in accordance with its original terms. ${ }^{44}$ The creditor whose debt obligation has been breached before bankruptcy usually will regard the effect of this curative power as akin to a redistribution from the aggrieved creditor to other creditors.

Nevertheless, one might pause before deeming these distributional effects of Chapter 11 reorganizations to be powerful evidence in favor of the revised creditors' bargain model. Chapter 11's distributional effects can support a

43 Moore's rule can be overkill even in the case of an insolvent firm. Much depends on the circumstances attending each creditor's relationship with the debtor. Although some creditors are likely to be among those affected by the draining of assets, others lack any claim to being adversely affected by the tainted transaction. They may have known of the debtor's condition or intentions. For this latter set of creditors, the rule of Moore is a windfall.

4411 U.S.C. $\S \S 1124,1129(\mathrm{a})(7), 1129$ (a)(8) (Supp. IV 1986). 
wide range of theories claiming that nonbankruptcy entitlements need to be modified. Whether the particulars of Chapter 11's distributional rules support Jackson and Scott's theory over other possible views of the reorganization process is an open question. For now, however, they offer one of the few comprehensive theoretical approaches to bankruptcy reorganizations and are entitled to draw whatever support the existing rules provide.

Jackson and Scott's emphasis on the relational aspects of parties in reorganization raises a related point. Bankruptcy's effect on the parties goes beyond the realization of firm value. Its rules about executory contracts, ${ }^{45}$ limitations on adequate protection, ${ }^{46}$ and the ability to cure defaults and decelerate accelerated loans ${ }^{47}$ all create longer-term relationships between debtors and interested parties. It is not just that bankruptcy reorganization is more appealing in the case of what Jackson and Scott label "multirelational firms." Bankruptcy rules promote the very characteristics that warrant reorganizations. Entities attempting to terminate relations with bankrupt firms often find themselves in longer-term relationships than they anticipated. If the foundation of cooperation is not merely trust but is also, as a cooperation theorist puts it, "the durability of the relationship,"48 bankruptcy law may be seen as trying to foster "a stable pattern of cooperation"49 with the attendant payoffs that cooperation yields. ${ }^{50}$

\section{The Problem of Amount}

One difficulty that Jackson and Scott face is probably endemic to any effort to explain bankruptcy's distributional rules. It is the problem of amount. Even if we concede that risk sharing drives the creditors' bargain, we still must ask how much risk would be shared ex ante. Does Jackson and Scott's treatment of ex ante risk-sharing agreements really translate into, for example, no compensation for secured parties for the delay in bankruptcy? Or might one expect some limits on the amounts of risk that parties would agree to share?

In pursuing this question, it is important to separate the direction of the risk-sharing effect from its magnitude. The effect's direction is easy for Jackson and Scott to identify. Distribution in bankruptcy generally flows more towards junior parties than does the rule-based distribution outside of bank-

45 See id. $\S 365$.

46 See id. § 361.

47 See id. $\$ 1124$.

48 R. Axelrod, The Evolution of Cooperation 182 (1984).

49 Id.

50 See generally Eisenberg, Bankruptcy in the Administrative State, Law \& Contemp. Probs. 3, Spring 1987, at 34-36 (discussing the relationship between bankruptcy and regulated industries). 
ruptcy. ${ }^{51}$ But they never address the size of this effect. Indeed, their theory could count as support almost any rule that shifts value from senior to junior interests in bankruptcy.

A process-oriented view of bankruptcy reduces the magnitude problem. If one emphasizes bankruptcy's promotion of bargained-for solutions, the problem of amounts becomes a less central concern. The parties' bargain establishes the size of distributional priorities. There is no fixed measure against which to assess the bargained-for quantities. Thus, an approach that emphasizes bargaining outcomes necessarily tells us less about which outcomes are "correct."

\section{CONCLUSION}

There is a price for having less definite views of what are correct and incorrect outcomes in bankruptcy. A broader range of acceptable arrangements means that creditors must plan on the basis of less certain outcomes. Much of this increased cost is, however, illusory. For state law and bankruptcy already treat a range of bargained solutions as acceptable. Until we acknowledge the greater latitude fostered by bargaining, bankruptcy law cannot begin to be faithful to nonbankruptcy distributional rules.

A new emphasis on bargaining creates one other problem. That many bargained solutions are acceptable does not mean that every bankruptcy rule that fosters bargaining automatically is justifiable. Which bankruptcy rules are faithful to state law distributional rules, as modified by solutions bargained in the shadow of state law, remains debatable. But that is a question we should begin to ask.

51 See, e.g., 11 U.S.C. $\S 547(b)$, (c)(5), (e)(3) (Supp. IV 1986) (effectively invalidating as preferences many security interests in after-acquired property; result favors unsecured creditors at the expense of secured creditors). 